\title{
Biological Control of Grape Crown Gall by Strain F2/5 Is Not Associated with Agrocin Production or Competition for Attachment Sites on Grape Cells
}

\author{
T. J. Burr, C. L. Reid, E. Tagliati, C. Bazzi, and S. Süle
}

First and second authors: Department of Plant Pathology, Cornell University, Geneva, NY 14456; third and fourth authors: Institute of Plant Pathology, University of Bologna, 40126 Bologna, Italy; and fifth author: Plant Protection Institute of Hungarian Academy of Sciences, P.O. Box 102, 1525 Budapest, Hungary.

Accepted for publication 2 April 1997.

\begin{abstract}
Burr, T. J., Reid, C. L., Tagliati, E., Bazzi, C., and Süle, S. 1997. Biological control of grape crown gall by strain F2/5 is not associated with agrocin production or competition for attachment sites on grape cells. Phytopathology 87:706-711.

Agrocin-minus mutants of nontumorigenic Agrobacterium vitis strain F2/5 controlled grape crown gall as well as the wild-type strain, indicating that agrocin is not a major factor in the mechanism of biological control. Relative levels of attachment to grape cells by tumorigenic and biocontrol strains were also measured. Attachment of tumorigenic strains (CG49 and K306) and biological control strains (F2/5 and agrocin-minus

mutant 1077) was often reduced when mixtures of the strains were applied. However, high populations $\left(10^{3}\right.$ to $\left.10^{5} \mathrm{CFU} / \mathrm{ml}\right)$ of all strains attached following mixed inoculations, suggesting that competition for attachment sites is also not a factor in the mechanism of biological control. Transfer of T-DNA to grape by CG49 was prevented or greatly inhibited in the presence of F2/5 or 1077 as measured by expression of the GUS reporter gene. The Ti plasmid virulence genes, however, were induced by exudates from grape shoots that had been inoculated with F2/5. Sonicated and autoclaved preparations of F2/5 and 1077 did not control crown gall or inhibit TDNA transfer. Control by F2/5 is specific to grape, since gall formation on tomato, sunflower, and Kalanchoe daigremontiana were not inhibited.
\end{abstract}

Agrobacterium vitis (21), which causes crown gall disease on grape, survives endophytically in grape and, therefore, is disseminated in propagation material $(2,15,29)$. Recently, methods for producing pathogen-free grapevines using shoot tip culture (3) and heat therapy (5) have been tested. However, once clean vines are obtained, it will be necessary to prevent them from becoming infected by $A$. vitis that may persist in decaying grape debris in soils (7).

A. radiobacter strain K-84 has been used successfully as a biological control of crown gall on several plant species (23). An agrocin produced by K-84 (agrocin 84 ) is thought to be a primary factor in the mechanism of control. K-84, however, is not effective for preventing infections on grape caused by A. vitis and, therefore, several laboratories have attempted to identify biological controls for grape crown gall $(17,27,31,33)$. Xiaoying isolated a nontumorigenic strain of $A$. tumefaciens biovar 1 (HLB-2) that inhibited growth of several $A$. vitis strains and suppressed development of crown gall on grape in the greenhouse $(8,33)$. Staphorst et al. (27) evaluated 16 strains, including strain F2/5 that inhibited growth of most $A$. vitis strains in vitro and greatly inhibited crown gall on grape in greenhouse experiments. Burr and Reid (6) reported that F2/5 produces an agrocin that is inhibitory to most $A$. vitis strains in vitro and F2/5 is effective for inhibiting tumor formation at wound sites on grape artificially inoculated with several A. vitis strains. F2/5 was most effective when wounds were inoculated at the same time as the pathogen or prior to the pathogen and at ratios of $1: 1$ (F2/5 to pathogen).

Prior to infection, tumorigenic Agrobacterium spp. attach to plant cells. It has been demonstrated that nontumorigenic strains of Agrobacterium may prevent infections by competing with tumorigenic strains for attachment sites on plant cells (23). The purpose of this research was to gain further insight into the

Corresponding author: T. J. Burr; E-mail address: tjb1@ cornell.edu

Publication no. P-1997-0502-01R

C) 1997 The American Phytopathological Society mechanism by which F2/5 inhibits crown gall of grape. Specifically, we wished to determine if agrocin production, competition for attachment sites, or both are related to the mechanism of biological control. We also examined the ability of F2/5 to prevent transfer of T-DNA by tumorigenic strains to grape and to prevent the induction of Ti plasmid virulence (vir) genes. In addition, the specificity of $\mathrm{F} 2 / 5$ for preventing crown gall on plants other than grape was determined.

\section{MATERIALS AND METHODS}

Bacterial strains. Strains used are listed in Table 1. All strains were stored at $-80^{\circ} \mathrm{C}$ in a medium containing (per $100 \mathrm{ml}$ ) $0.8 \mathrm{~g}$ of nutrient broth (Difco Laboratories, Detroit), $15 \mathrm{ml}$ of glycerol, $0.2 \mathrm{~g}$ of yeast extract, and $0.5 \mathrm{~g}$ of glucose.

Transposon mutagenesis. F2/5 and Escherichia coli strain S17-1, carrying the transposon Tn5 on pSUP2021 (24), were grown for $48 \mathrm{~h}$ at $28^{\circ} \mathrm{C}$ on potato dextrose agar (PDA) (Difco Laboratories) and on Luria-Bertani medium (19) amended with kanamycin $(50 \mu \mathrm{g} / \mathrm{ml})$, respectively. Growth from two culture plates of each strain were suspended in $1.0 \mathrm{ml}$ of sterile distilled water (SDW), and suspensions of the bacteria were combined. Volumes of $250 \mu \mathrm{l}$ of the mixed suspension were spread onto the surface of four PDA plates and incubated at $28^{\circ} \mathrm{C}$ for $48 \mathrm{~h}$. Resulting bacterial growth from the matings was scraped from the plates, suspended in SDW, and dilution-plated on $\mathrm{AB}$ minimal salts medium $(9,32)$ containing kanamycin $(50 \mu \mathrm{g} / \mathrm{ml})$. Transconjugants that grew within 3 to 4 days were recultured on the same medium and then assayed for their ability to inhibit growth of $A$. vitis strain K306 in vitro.

In vitro antibiosis assays were done by first making suspensions of transconjugants containing about $10^{8} \mathrm{CFU} / \mathrm{ml}$ (optical density of 0.1 at $600 \mathrm{~nm}\left[\mathrm{OD}_{600}\right]$ determined with spectrophotometer). Twenty-four transconjugants were spotted (5- $\mu$ l volumes) on each 9-cm-diameter petri dish containing about $10 \mathrm{ml}$ of mannitolglutamate (MG) medium (20). Plates were incubated for $48 \mathrm{~h}$ at 
$28^{\circ} \mathrm{C}$, after which bacterial cells were killed by chloroform vapor (6), and bacterial growth was scraped from the plates. The surfaces of the plates were then sprayed until lightly wetted with a suspension of K306 containing about $10^{8} \mathrm{CFU} / \mathrm{ml}$. Plates were incubated at $28^{\circ} \mathrm{C}$, and the presence of inhibition zones around transconjugants were observed after $48 \mathrm{~h}$. Strain F2/5 was spotted on all plates as a positive control. Transconjugants that failed to inhibit growth of K306 were retested at least three times.

Southern hybridizations. Southern hybridizations were done on F2/5 and agrocin-minus mutant strains $(1076,1077$, 1078, and 1079) to determine if the transposon had inserted into a plasmid or the bacterial chromosome. Plasmids and total genomic DNA were isolated from $A$. vitis strains as previously reported $(4,7,25)$. Genomic DNA was digested overnight in EcoRV. Plasmids and digested genomic DNA were electrophoresed separately at $5 \mathrm{~V} / \mathrm{cm}$ in $0.7 \%$ agarose in Tris-borate-EDTA and then visualized by staining with ethidium bromide. DNA was then Southern-transferred to nylon transfer membranes by alkaline transfer. Plasmids and digested total genomic DNA were hybridized with DNA from a pUT plasmid carrying mini-Tn5Km2 (kanamycin-resistance gene) (12) that was labeled by random primed incorporation of digoxigenin-labeled deoxyuridine-triphosphate using a nonradioactive DNA labeling kit (Genius; Boehringer Mannheim Biochemicals, Indianapolis, IN).

Membranes were prehybridized in hybridization solution $(5 \times$ $\mathrm{SSC}$ [ $1 \times \mathrm{SSC}$ is $0.15 \mathrm{M} \mathrm{NaCl}$ plus $0.015 \mathrm{M}$ sodium citrate], $0.5 \%$ [wt/vol] blocking reagent, $0.1 \%$ [wt/vol] $N$-lauroyl sarcosine sodium salt, and $0.02 \%$ [wt/vol] sodium dodecyl sulfate [SDS]) at $68^{\circ} \mathrm{C}$ for $135 \mathrm{~min}$. Hybridizations were done at $68^{\circ} \mathrm{C}$ for $18 \mathrm{~h}$ in $0.03 \mathrm{ml}$ of hybridization solution $/ \mathrm{cm}^{2}$ of membrane containing 25 ng of labeled, denatured $\mathrm{DNA} / \mathrm{ml}$ of hybridization solution. The DNA probe was denatured for $10 \mathrm{~min}$ at $95^{\circ} \mathrm{C}$ and quick-chilled on ice for 2 to $5 \mathrm{~min}$ before it was added to the hybridization solution. Following posthybridization rinses, blocking, and incubation with antibody-conjugate solution and subsequent rinses, the membrane was placed in a hybridization bag that was open on two sides and saturated with a sufficient quantity of Lumi-Phos 530 (for chemiluminescent detection of alkaline phosphatase; Boehringer Mannheim Biochemicals) to fully wet the membrane. It was then incubated in the dark (covered with aluminum foil) for $1 \mathrm{~min}$. The excess Lumi-Phos 530 was then drained from the hybridization bag, and the bag sealed, wrapped in foil, and incubated at $37^{\circ} \mathrm{C}$ for $30 \mathrm{~min}$. The membrane was subsequently placed in a film cassette, exposed to X-ray film (Kodak XAR; Eastman Kodak Co., Rochester, NY) for $8 \mathrm{~min}$, and then developed.

Gall inhibition assays. The ability of agrocin-minus mutants 1076, 1077, 1078, and 1079 to inhibit gall formation by A. vitis strains CG49 and K306 was compared with that of F2/5. Woody stems of potted 'Chardonnay' grapevines were inoculated using procedures that were previously reported (6). Briefly, wounds were made with an electric drill (6-mm diameter) and inoculated with $75 \mu \mathrm{l}$ of bacterial cell suspensions containing approximately equal numbers of biological control and tumorigenic bacterial strains. Bacterial cell suspensions were made to $\mathrm{OD}_{600} 0.1$, corresponding to about $10^{8} \mathrm{CFU} / \mathrm{ml}$, and populations were verified by plating on PDA or PDA amended with kanamycin. For each replication of the experiment, three inoculations were made to each of three plants, and inoculation sites were wrapped with Parafilm. The numbers of inoculation sites at which galls developed and the crosssectional area (at widest point) of each gall were recorded 8 weeks after inoculation. SDW was applied as a negative control, and strains CG49 and K306 mixed with SDW as positive controls. The experiment was repeated four times. Differences in gall crosssectional areas were analyzed using SAS General Linear Models $t$ test (SAS Institute, Cary, NC).

Strains F2/5 and 1077 were also tested for their ability to inhibit gall formation by CG49 and K306 on sunflower (Helianthus annuus L.), tomato (Lycopersicon esculentum Mill.), and Kalanchoe daigremontiana Hamet \& E. Perrier. Inoculation mixtures were made as above, and stems of potted plants were inoculated by placing 2- $\mu$ l drops of strains, alone and in mixtures, at sites in which wounds were made with a sterile pin. The incidence of galls was recorded after 3 weeks. The experiment was repeated twice with K306 and once for CG49.

Attachment assays. Green, actively growing shoots were collected from potted grapevines (cv. Chardonnay). Sections of second, third, and fourth internodes having approximately the same diameters were cut from the shoots and surface-disinfested by shaking them submersed in $95 \%$ ethanol for 2 min and then in $10 \%$ Clorox for $5 \mathrm{~min}$. They were then rinsed three times in SDW. The internodes were cut in lengths of about $1 \mathrm{~cm}$, and the apical end was embedded in water agar in petri dishes (12 sections/ plate). Bacterial strains CG49, F2/5, and 1077 were grown on PDA or PDA plus kanamycin for $48 \mathrm{~h}$ at $28^{\circ} \mathrm{C}$, and then suspended in SDW to a concentration of $\mathrm{OD}_{600}$ 0.1. Serial dilutions of suspensions were plated. The exposed basal end of each shoot piece was then inoculated with $2 \mu \mathrm{l}$ of the following treatments: SDW, CG49, F2/5, 1077, and CG49 combined with F2/5, and CG49 combined with 1077 (mixtures of strains containing equal volumes of each bacterial suspension). Twelve shoot sections were inoculated with each treatment. Lids were placed on the petri dishes, and internodes were incubated for $3 \mathrm{~h}$. Another experiment was done substituting K306 for CG49. All experiments were repeated at least once.

The numbers of bacterial cells in each treatment that attached to the cut ends of the internodes were determined. The inoculated ends were excised (3- to 4-mm thickness), placed in tubes containing $10 \mathrm{ml}$ of SDW, and vortexed vigorously for $30 \mathrm{~s}$. Water was decanted from the tube, replaced with another $10 \mathrm{ml}$, and vortexed again. The vortexing in fresh water was done a total of three times. Three groups of four internode sections each were triturated in $1 \mathrm{ml}$ of SDW in a microfuge tube, and populations of bacteria that had attached to the grape cells were determined by dilution-plating in triplicate on a medium, developed by Roy and Sasser, that is semiselective for A. vitis (RS) (22) and on PDA. Colonies were counted after 3 days on PDA and after 7 days on RS. CG49 could be distinguished from F2/5 and 1077 by colony morphology on PDA, and K306 could be distinguished from the other strains on RS.

Effect on T-DNA transfer. We wished to determine whether strains F2/5 and 1077 prevent the transfer of the Ti plasmid TDNA to grape. CG49 was first transformed with p35SGUSINT (carries the uidA reporter gene and an eukaryotic intron driven by

TABLE 1. Bacterial strains used in this study

\begin{tabular}{|c|c|c|}
\hline Designation & Characteristics & Origin or reference \\
\hline \multicolumn{3}{|l|}{ Agrobacterium vitis } \\
\hline CG49 & Nopaline Ti plasmid & Burr, NY \\
\hline K306 & Octopine Ti plasmid & A. Kerr, Australia \\
\hline CG49(p35SGUSINT) & $\mathrm{Km}^{\mathrm{R}}$ & This study \\
\hline K306(p35SGUSINT) & $\mathrm{Km}^{\mathrm{R}}$ & This study \\
\hline CG49(pSM243cd) & $\mathrm{Km}^{\mathrm{R}}, \mathrm{Cb}^{\mathrm{R}}$ & This study \\
\hline K306(pSM243cd) & $\mathrm{Km}^{\mathrm{R}}, \mathrm{Cb}^{\mathrm{R}}$ & This study \\
\hline $\mathrm{F} 2 / 5$ & $\begin{array}{l}\text { Agrocin }^{+} \\
\text {nontumorigenic }\end{array}$ & $\begin{array}{l}\text { Staphorst et al., } 1985 \\
\text { (South Africa) }\end{array}$ \\
\hline 1076 & Agrocin $^{-} \mathrm{F} 2 / 5, \mathrm{Km}^{\mathrm{R}}$ & This study \\
\hline 1077 & Agrocin $^{-} \mathrm{F} 2 / 5, \mathrm{Km}^{\mathrm{R}}$ & This study \\
\hline 1078 & Agrocin $^{-} \mathrm{F} 2 / 5, \mathrm{Km}^{\mathrm{R}}$ & This study \\
\hline 1079 & Agrocin $^{-}$F2/5, $\mathrm{Km}^{\mathrm{R}}$ & This study \\
\hline \multicolumn{3}{|l|}{ Escherichia coli } \\
\hline S17-1(pSUP2021) & $\mathrm{Km}^{\mathrm{R}}$ & Simon et al., 1983 \\
\hline S17-1(p35SGUSINT) & $\mathrm{Km}^{\mathrm{R}}$ & Vancanneyt et al., 1990 \\
\hline MC1061(pSM243cd) & $\mathrm{Km}^{\mathrm{R}}, \mathrm{Cb}^{\mathrm{R}}$ & Stachel and Zambryski, 1986 \\
\hline HB101(pRK2013) & $\mathrm{Km}^{\mathrm{R}}$ & Figurski and Helinski, 1979 \\
\hline \multicolumn{3}{|l|}{ Other } \\
\hline A348(pSM243cd) & A. tumefaciens biovar 1 & Stachel and Zambryski, 1986 \\
\hline
\end{tabular}


the $35 \mathrm{~S}$ promoter) (30). CG49 was grown on PDA and E. coli strain S17-1 (p35SGUSINT) was grown on LB medium amended with kanamycin. Transconjugants of CG49 carrying p35SGUSINT were derived by mating the A. vitis strains with S17-1 following the protocol described above for Tn5 mutagenesis and selecting transconjugants on minimal medium plus kanamycin.

CG49 and CG49(p35SGUSINT), alone and in combination with F2/5 and 1077, were inoculated on grape internodes (cvs. Cabernet Sauvignon and Catawba) as described above. Internodes were incubated in baby food jars containing half-strength Gamborg's B5 basal salt mixture (Sigma Chemical Co., St. Louis) amended with $10 \mathrm{~g} /$ liter of sucrose and $0.6 \%$ agar without hormones. Eight internodes were inoculated per jar, and two jars were used for each treatment.

To measure GUS activity, thin sections of the inoculated ends of the internodes were collected 14 days after inoculation. Sections were rinsed in $0.1 \mathrm{M}$ phosphate buffer ( $\mathrm{pH} 7.0)$ three times and then placed in individual wells of 96-well microtiter plates to which $100 \mu \mathrm{l}$ of substrate solution was added. To make the substrate solution, a desired quantity of 5-bromo-4-chloro-3-indolyl-

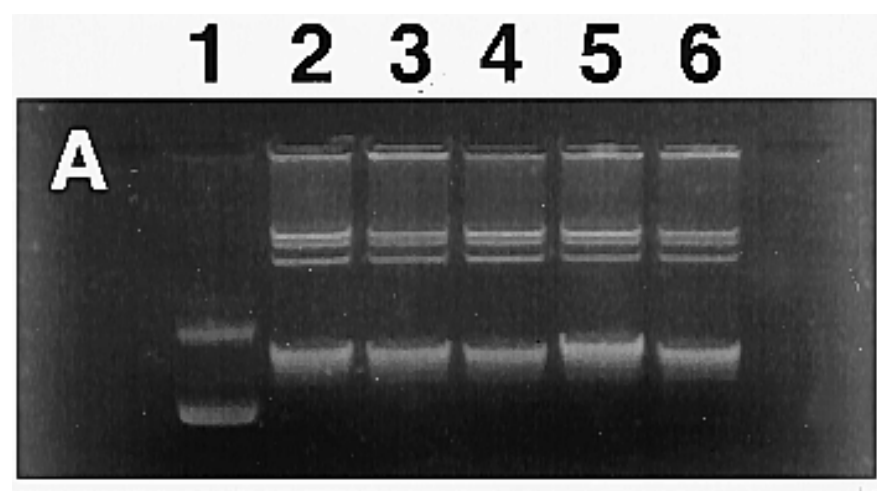

B
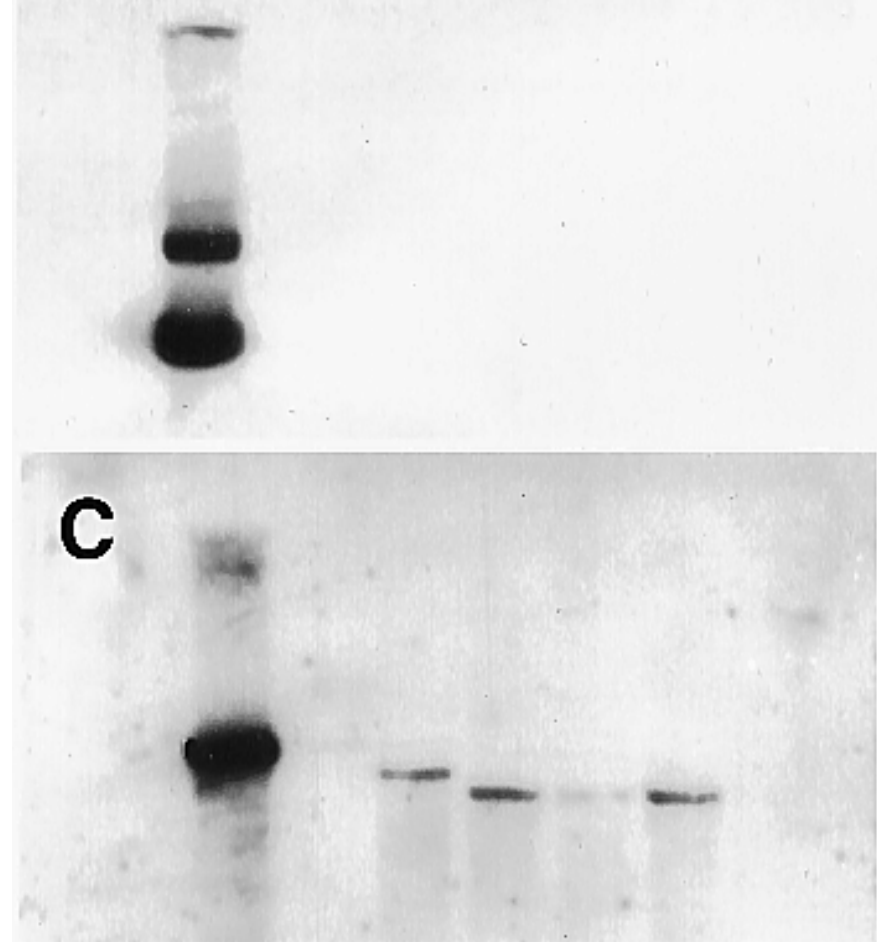

Fig. 1. A, Plasmid profiles; B, Southern hybridization of plasmids; and C, hybridization of EcoRV-digested total genomic DNA. All hybridizations were done by probing with mini-Tn $5 \mathrm{Km} 2$ as described in text. Lanes correspond to strains: $1=\mathrm{S} 17-1(\mathrm{pSUP} 2021), 2=\mathrm{F} 2 / 5,3=1076,4=1077,5=$ 1078 , and $6=1079$.
D-glucuronic acid (X-gluc) was first dissolved in a couple of drops of $\mathrm{N}, \mathrm{N}$-dimethyl formamide and then added at a concentration of 1 $\mathrm{mg} / \mathrm{ml}$ of buffer consisting of $980 \mu \mathrm{l}$ of $0.1 \mathrm{M}$ phosphate buffer $(\mathrm{pH} 7.0)$ and $10 \mu \mathrm{l}$ each of potassium ferricyanide and potassium ferricyanide $(5 \mathrm{mM})$. Lids were placed on plates, wrapped in Parafilm, and the plant sections were incubated overnight at $37^{\circ} \mathrm{C}$ and then rinsed with phosphate buffer before viewing them under a dissecting scope for the presence of blue cells. After the first experiment showed that F2/5 and 1077 inhibited grape transformation, the experiment was repeated two additional times and included sonicated (in ultrasonicator for $60 \mathrm{~s}$ ) and autoclaved preparations of F2/5 and 1077.

Effect of F2/5 on vir induction. A previously employed assay (28) was used to determine if the induction of vir in CG49 and K306 is inhibited by exudates from grape shoots that were inoculated with F2/5 and 1077. Transconjugants of CG49 and K306 carrying pSM243cd (containing a virB::lacZ fusion) (26) were made by triparental-mating with $E$. coli strain MC1061 carrying pSM243cd and with E. coli strain HB101 carrying the helper plasmid pRK2013 (13).

In vitro-grown grape shoot pieces (Vitis vinifera cv. Narancsizü), about $10 \mathrm{~mm}$ in length, were submersed for $20 \mathrm{~min}$ in suspensions of F2/5 or 1077 containing about $10^{8} \mathrm{CFU} / \mathrm{ml}$. Control shoot pieces were submersed in SDW. CG49(pSM243cd), K306(pSM243cd), and A. tumefaciens biovar 1 strain A348(pSM243cd) (as a positive control) were grown for $48 \mathrm{~h}$ on low-phosphate $\mathrm{AB}$ sucrose medium, which is optimized for vir induction assays (32). The medium contains $3 \%$ sucrose, $\mathrm{AB}$ salts, $2.5 \mathrm{mM}$ phosphate buffer, 20 $\mathrm{mM}$ morpholineethanesulfonic acid (MES), and $50 \mu \mathrm{g} / \mathrm{ml}$ each of ampicillin and kanamycin. The medium was adjusted to $\mathrm{pH} 5.5$ for vir induction. The bacteria were then suspended in the same liquid medium (to about $10^{8} \mathrm{CFU} / \mathrm{ml}$ ) without antibiotics. They were then spread on the surface of the above medium containing $1 \%$ agar, $20 \mathrm{mg}$ of X-Gal (5-bromo-4-chloro-3-indolyl- $\beta$-D-galactopyranoside), and $20 \mathrm{mg}$ of IPTG (isopropyl- $\beta$-D-thiogalactopyranoside)/liter. The grape shoot pieces were placed on the surface of the medium, and the appearance of blue color around the cut ends of the shoots (denoting production of $\beta$-galactosidase and, thus, vir induction) was monitored 2 to 4 days later.

TABLE 2. Effect of F2/5 and 1077 on attachment of CG49 and K306 to grape ${ }^{\mathrm{a}}$

\begin{tabular}{lccc}
\hline & \multicolumn{3}{c}{ Mean population $^{\mathrm{b}}$} \\
\cline { 2 - 4 } Coinoculant & CG49/K306 $^{\mathrm{c}}$ & $\mathrm{F} 2 / 5$ & 1077 \\
\hline CG49 & $1.1 \times 10^{5} \mathrm{u}^{\mathrm{d}}$ & $1.5 \times 10^{5} \mathrm{w}$ & $7.2 \times 10^{4} \mathrm{y}$ \\
Water & $\ldots$ & $5.7 \times 10^{4} \mathrm{x}$ & $3.0 \times 10^{4} \mathrm{z}$ \\
CG49 & $4.1 \times 10^{4} \mathrm{v}$ & $\ldots$ & $\ldots$ \\
F2/5 & $3.2 \times 10^{4} \mathrm{v}$ & $\ldots$ & $\ldots$ \\
1077 & & & \\
K306 & $6.5 \times 10^{3} \mathrm{u}$ & $6.3 \times 10^{3} \mathrm{w}$ & $6.1 \times 10^{3} \mathrm{y}$ \\
Water & $\ldots$ & $8.0 \times 10^{3} \mathrm{w}$ & $3.2 \times 10^{3} \mathrm{z}$ \\
K306 & $6.7 \times 10^{3} \mathrm{u}$ & $\ldots$ & $\ldots$ \\
F2/5 & $4.8 \times 10^{3} \mathrm{u}$ & $\ldots$ & $\ldots$ \\
1077 & & $\ldots$ & $\ldots$
\end{tabular}

${ }^{a}$ Initial bacterial suspensions $(\mathrm{CFU} / \mathrm{ml})$ used with CG49 were CG49 $=1.0 \times$ $10^{8}, \mathrm{~F} 2 / 5=1.3 \times 10^{8}$, and $1077=9.0 \times 10^{7}$; and those with $\mathrm{K} 306$ were $\mathrm{K} 306=7.0 \times 10^{7}, \mathrm{~F} 2 / 5=4.0 \times 10^{7}$, and $1077=5.0 \times 10^{7}$ mixed with equal volumes of water or coinoculant and applied to grape shoots as described in text.

${ }^{b}$ Mean populations $(\mathrm{CFU} / \mathrm{ml})$ of strains that attached to grape shoots following inoculations with other strains were determined by plating on potato dextrose agar (PDA) or RS media. Colonies of CG49 were distinguished from F2/5 and 1077 by morphology on PDA. Colonies of K306 were distinguished from colonies of other strains on RS medium.

${ }^{c}$ Mean populations of CG49 for the first half of the table and of K306 for the second half.

${ }^{\mathrm{d}}$ Values in the same column that are followed by different letters are significantly different determined by the SAS General Linear Models $t$ test $(P=$ $0.05)$. 


\section{RESULTS}

Agrocin-minus F2/5 mutants. About 3,000 Tn5 mutants of F2/5 were screened for their capacity to inhibit growth of K306 in vitro. Four agrocin-minus mutants, 1076, 1077, 1078, and 1079, were isolated. Plasmid profiles of the mutant strains (Fig. 1A) revealed identical patterns to F2/5, and none of the plasmids hybridized with the mini-Tn5Km2 probe (Fig. 1B). In all cases, digested genomic DNA from mutant strains revealed a single band of approximately the same size when hybridized with the Tn $5 \mathrm{Km} 2$ probe (Fig. 1C).

To determine if the mutations may not be affecting agrocin production but rather the export of agrocin across the outer membrane of the bacterial cell, strains F2/5 and 1077 were grown on MG medium and then an aqueous suspension of about $10^{8} \mathrm{CFU} / \mathrm{ml}$ was ultrasonicated for $3 \mathrm{~min}$ and spotted on MG medium. After the spots dried, the plates were sprayed with a suspension of K306 as described above. Zones of growth inhibition were only observed around the F2/5 spots, indicating that mutants were unable to produce the agrocin.

Gall inhibition. Agrocin-minus derivatives 1076, 1077, 1078, and 1079 controlled crown gall on grape as well as did wild-type F2/5 (Fig. 2). Galls did not develop, or were greatly suppressed, on plants that were coinoculated with the F2/5 or mutants mixed with CG49 or K306. As observed previously, K306 is more virulent on grape than is CG49, in that more inoculation sites develop galls and they are generally larger in size (6).

Strains F2/5 and 1077, however, failed to inhibit gall formation by CG49 and K306 on sunflower, tomato, or $K$. daigremontiana. All plants that were coinoculated with the biological controls and pathogens developed galls at all inoculation sites, and the galls appeared identical to those that developed on plants inoculated with the pathogens alone.

Attachment. Following coinoculation with F2/5 and 1077, populations of CG49 that attached to grape shoot tissues were reduced significantly, whereas populations of K306 were not (Table 2). Populations of F2/5 and 1077 that attached to the shoots also were reduced significantly when coinoculated with CG49. Strain 1077 attachment was reduced significantly when coinoculated with K306. Although the reductions in attachment were, in some cases, statistically significant, they were no greater than one log unit as compared with attachment in the absence of coinoculant strains. Therefore, high numbers of CG49 and K306 cells still attached to grape, even in the presence of F2/5 and 1077. It was demonstrated that the populations of CG49 and K306 that were able to attach to the grape shoots in the presence of F2/5 and 1077 (about $10^{4} \mathrm{CFU} / \mathrm{ml}$ ) were adequate to cause crown gall on shoot pieces (T. J. Burr, unpublished data). Therefore, the mechanism by which F2/5 inhibits crown gall of grape does not appear to be associated with competition for attachment sites on grape cells.

T-DNA transfer and vir induction. Strains F2/5 and 1077 greatly affected the ability of tumorigenic strains to transfer TDNA to grapes as determined by the presence of blue cells (GUS expression) in inoculated internode sections. A total of five to six thin sections from each of 16 internodes were observed for each inoculation made to 'Cabernet Sauvignon' and 'Catawba'. Internodes that were inoculated with wild-type CG49 had no blue cells, whereas those inoculated with CG49(p35SGUSINT) had abundant blue cells at the inoculated ends. In contrast, no blue cells were observed in tissues that were inoculated with the mixture of CG49(p35SGUSINT) and F2/5 or with CG49(p35SGUSINT) and 1077. In some cases, these shoots developed slight swellings that possibly resulted from normal callus formation, however, none had observable blue cells. Internodes that were inoculated with CG49(p35SGUSINT) mixed with sonicated or autoclaved F2/5 and 1077 had abundant blue cells in all internodes, resembling those inoculated with CG49(p35SGUSINT) alone. No differ- ences were observed between experiments done with 'Cabernet Sauvignon' or 'Catawba'.

Treating grape shoot pieces with F2/5 or 1077 did not prevent their exudates from inducing vir in strains CG49 or K306. Four transconjugants of CG49 and two of K306 carrying pSM243cd were compared with the positive control, A348(pSM243cd). Blue-pigmented bacterial growth of CG49(pSM243cd) and K306(pSM243cd) was observed within 48 to $72 \mathrm{~h}$ on the agar plates around the cut ends of the shoots that were treated with F2/5, 1077, or water (indicative of $\beta$-galactosidase activity).

\section{DISCUSSION}

Two possible mechanisms by which F2/5 may inhibit crown gall of grape, i.e., antibiosis by an agrocin and competition for attachment sites on grape, were investigated. Although F2/5 produces an agrocin that inhibits growth of many A. vitis strains in vitro, the agrocin is apparently not a major factor in suppressing crown gall on grape, since agrocin-minus mutants of F2/5 provided the same level of crown gall control as the wild-type strain. This finding is particularly interesting since F2/5 was first selected as a potential candidate for biological control because of its in vitro antibiosis to $A$. vitis (27). We previously found that at least one strain of A. vitis (CG78) that is sensitive to the agrocin of F2/5 in vitro is not controlled by F2/5 on grape (6). Therefore, the mechanism by which F2/5 inhibits crown gall on grape is apparently not related to agrocin production and is different from that by which $A$. radiobacter strain K-84 controls crown gall on other hosts. Production of agrocin 84 is generally believed to be a major contributing factor to biological control by K-84, although other factors such as competition for attachment sites on plant cells (11) and the production of agrocins other than agrocin 84 (10) may also be involved.

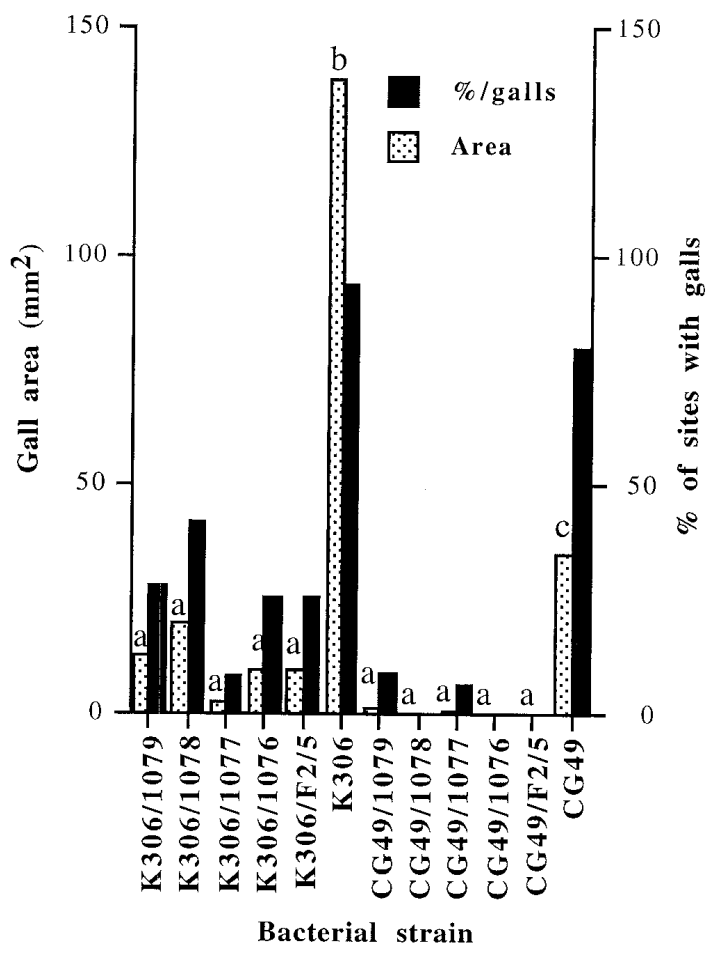

Fig. 2. Effect of F2/5 and agrocin-minus mutants 1076, 1077, 1078, and 1079 on the development of crown gall of grape by CG49 and K306. Suspensions of bacteria containing about $10^{8} \mathrm{CFU} / \mathrm{ml}$ of CG49 or K306 were mixed 1:1 with water, F2/5, or agrocin-minus mutants before inoculating woody stems of grape as described in text. Values for gall size in columns followed by different letters differ significantly as determined by the SAS General Linear Models $t$ test $(P=0.05)$. 
An early event in tumorigenesis of Agrobacterium spp. is the attachment of the bacterium to host plant cells (16). At least three chromosomal virulence genes are known to be involved in attachment of $A$. tumefaciens to various plant species. It has been demonstrated that some nontumorigenic strains efficiently compete for attachment sites on plant cells and, thereby, inhibit attachment and infection by tumorigenic strains (18). It was previously demonstrated that $A$. vitis attaches more efficiently than $A$. tumefaciens to grape roots and that polygalacturonase production by $A$. vitis may be associated with attachment (1). Therefore, we examined the relative abilities of F2/5, 1077, CG49, and K306, alone and in combinations, to attach to grape cells. Our results do not support the hypothesis that F2/5 is preventing crown gall by significantly inhibiting the attachment of tumorigenic A. vitis to grape. Although there was a significant reduction in attachment of the tumorigenic strains following inoculations with some strain mixtures, this seemed to be a nonspecific phenomenon, since even attachment of biological control strains F2/5 and 1077 was reduced when they were inoculated together with CG49.

The effectiveness of F2/5 and agrocin-minus mutants for crown gall control was measured by observing gall development on plants and determining GUS expression in plants inoculated with derivatives of CG49 and K306 carrying p35GUSINT. Gall formation and GUS expression were often completely prevented, indicating that the T-DNA of the pathogens is not transferred to grape and expressed in the grape genome. In contrast, galls formed on sunflower, tomato, and $K$. daigremontiana that were inoculated with F2/5-pathogen mixtures, illustrating that CG49 and K306 remain viable (6) and tumorigenic in the bacterial mixtures. These results suggest that F2/5 may be inducing a resistance reaction in grape or that its inhibitory activity on the pathogen is directly related to its interaction with grape.

Plant signal compounds are able to induce the vir genes that are carried on the Ti plasmids of tumorigenic Agrobacterium spp. (16). These genes are responsible for packaging and transfer of TDNA to the plant. We sought to determine if, following treatment of grape shoots with F2/5 and 1077, exudates from the inoculated shoots would be altered in their ability to induce vir in A. vitis. However, in all cases, vir was induced by exudates from grape shoots that had been treated with both strains. Vir induction was determined by measuring induction of a virB::lacZ fusion carried in $\mathrm{pSM} 243 \mathrm{~cd}$. The virB was cloned from $A$. tumefaciens strain A6. It has been reported that some vir regions of $A$. vitis Ti plasmids may differ substantially from those that have been mapped in A. tumefaciens strains (14). Therefore, it was interesting to note that vir products from wild-type CG49 and K306 were able to induce the A6 virB in pSM243cd. Using this same method to measure differences in vir induction by exudates from crown gall-susceptible and -resistant grape genotypes, it was found that vir is induced equally well in both groups (28). Therefore, in crown gall-susceptible grape shoots treated with F2/5 and in resistant grape genotypes, the prevention of $\mathrm{T}$ DNA expression in the plants does not result from failure of vir induction.

Biological control of grape crown gall is likely to provide an effective means for preventing infection of vines that are to be planted in vineyards where grapes were grown previously. An understanding of the mechanism of control will be important for determining the most efficient way of preparing and applying the biological control strains in commercial agriculture. Ideally, F2/5 applied to vines at planting time would colonize them systemically, similar to tumorigenic A. vitis, and provide protection against crown gall for an extended period of time. Several factors including the timing of F2/5 applications in relation to infection by $A$. vitis, the length of the protection period after application of $\mathrm{F} 2 / 5$, and the possible need for repeated applications of F2/5 during the life of the vineyard are being studied.

\section{ACKNOWLEDGMENTS}

This research was partially funded by the New York State Wine and Grape Foundation, Cornell Center for Advanced Technology in Biotechnology, and UST Inc.

\section{LITERATURE CITED}

1. Brisset, M. N., Rodriguez-Palenzuela, P., Burr, T. J., and Collmer, A. 1991. Attachment, chemotaxis, and multiplication of Agrobacterium vitis and A. tumefaciens biovar 1 on grapevine and pea. Appl. Environ. Microbiol. 57:3178-3182.

2. Burr, T. J., and Katz, B. H. 1984. Grapevine cuttings as potential sites of survival and means of dissemination of Agrobacterium tumefaciens. Plant Dis. 68:976-978.

3. Burr, T. J., Katz, B. H., Bishop, A. L., Meyers, C. A., and Mittak, V. L. 1988. Effect of shoot age and tip culture propagation on grapes on systemic infestation by Agrobacterium tumefaciens biovar 3. Am. J. Enol. Vitic. 39:67-70.

4. Burr, T. J., Norelli, J. L., Katz, B. H., and Bishop, A. L. 1990. Use of Ti plasmid DNA probes for determining tumorigenicity of Agrobacterium strains. Appl. Environ. Microbiol. 56:1782-1785.

5. Burr, T. J., Ophel, K., Katz, B. H., and Kerr, A. 1989. Effect of hot water treatment on systemic Agrobacterium tumefaciens biovar 3 in dormant grape cuttings. Plant Dis. 73:242-245.

6. Burr, T. J., and Reid, C. L. 1993. Biological control of grape crown gall with nontumorigenic Agrobacterium vitis strain F2/5. Am. J. Enol. Vitic. 45:213-219.

7. Burr, T. J., Reid, C. L., Yoshimura, M., Momol, E. A., and Bazzi, C. 1995. Survival and tumorigenicity of Agrobacterium vitis in living and decaying grape roots and canes in soil. Plant Dis. 79:677-682.

8. Cheng, Z.-M. 1991. Strategies for genetic engineering of grapevines for crown gall disease resistance and attempted transformation via Agrobacterium Ti plasmid vectors and biolistic process. Ph.D. thesis. Cornell University, Geneva, NY.

9. Chilton, M., Currier, T. C., Farrand, S. K., Bendrich, A. J., Gordon, M P., and Nester, E. W. 1974. Agrobacterium tumefaciens DNA and PS8 bacteriophage DNA not detected in crown gall tumorigenesis. Proc. Natl. Acad. Sci. U.S.A. 71:3672-3676.

10. Clare, B. G. 1993. Agrobacterium: Biological plant disease control. Pages 129-146 in: Advanced Engineered Pesticides. L. Kim, ed. Marcel Dekker, Inc., New York.

11. Cooksey, D. A., and Moore, L. W. 1982. Biological control of crown gall with an agrocin mutant of Agrobacterium radiobacter. Phytopathology 72:919-921.

12. de Lorenzo, V., Herrero, M., Jakubzik, U., and Timmis, K. N. 1990. Mini-Tn5 transposon derivatives for insertion mutagenesis, promoter probing, and chromosomal insertion of cloned DNA in Gram-negative Eubacteria. J. Bacteriol. 172:6568-6572.

13. Figurski, D., and Helinski, D. R. 1979. Replication of an origin-containing derivative of plasmid RK2 dependent on a plasmid function provided in Trans. Proc. Natl. Acad. Sci. U.S.A. 76:1648-1652.

14. Gerard, J. C., Canaday, J., Szegedi, E., Salle, H., and Otten, L. 1992. Physical map of the vitopine Ti plasmid pTiS4. Plasmid 28:146-156.

15. Goodman, R. N., Butrov, D., and Tarbah, F. 1987. The occurrence of Agrobacterium tumefaciens in grapevine-propagating material and a simplified indexing system. Am. J. Enol. Vitic. 38:189-193.

16. Kado, C. I. 1993. Agrobacterium-mediated transfer and stable incorporation of foreign genes in plants. Pages 243-254 in: Bacterial Conjugation. D. B. Clewell, ed. Plenum Press, New York.

17. Liang, Y., Di, Y., Zhao, J., and Ma, D. 1990. A biotype 3 strain of Agrobacterium radiobacter inhibits crown gall formation on grapevine. Acta Microbiol. Sin. 30:165-171.

18. Lippincott, B. B., and Lippincott, J. A. 1969. Bacterial attachment to a specific wound site as an essential stage in tumor initiation by Agrobacterium tumefaciens. J. Bacteriol. 97:620-628.

19. Maniatis, T., Fritsch, E. F., and Sambrook, J. 1982. Molecular Cloning: A Laboratory Manual. Cold Spring Harbor Laboratory, Cold Spring Harbor, NY.

20. Moore, L. W., Kado, C. I., and Bouzar, H. 1988. Agrobacterium. Pages 16-36 in: Laboratory Guide for Identification of Plant Pathogenic Bacteria. 2nd ed. N. W. Schaad, ed. The American Phytopathological Society, St. Paul, MN.

21. Ophel, K., and Kerr, A. 1990. Agrobacterium vitis sp. nov. for strains of Agrobacterium tumefaciens biovar 3 from grapevines. Int. J. Syst. Bacteriol. 40:236-241.

22. Roy, M. A., and Sasser, M. 1983. A medium selective for Agrobacterium tumefaciens biotype 3. (Abstr.) Phytopathology 73:810.

23. Shim, J.-S., Farrand, S. K., and Kerr, A. 1987. Biological control of 
crown gall: Construction and testing of new biocontrol agents. Phytopathology 77:463-466.

24. Simon, R., Priefer, U., and Puhler, A. 1983. A broad host range mobilization system for in vivo genetic engineering: Transposon mutagenesis in gram negative bacteria. Bio/Technology 1:784-791.

25. Slota, J. E., and Farrand, S. K. 1982. Genetic isolation and physical characterization of pAGK84, the plasmid responsible for agrocin 84 production. Plasmid 8:175-186.

26. Stachel, S. E., and Zambryski, P. 1986. VirA and virG control the plantinduced activation of the T-DNA transfer process of $A$. tumefaciens. Cell 46:325-333.

27. Staphorst, J. L., van Zyl, F. G. H., Strijdom, B. W., and Groenewold, Z. E. 1985. Agrocin-producing pathogenic and nonpathogenic biotype-3 strains of Agrobacterium tumefaciens active against biotype-3 pathogens. Curr. Microbiol. 12:45-52.

28. Süle, S., Mozsar, J., and Burr, T. J. 1994. Crown gall resistance in Vitis spp. and grapevine rootstocks. Phytopathology 84:607-611.
29. Tarbah, F. A., and Goodman, R. N. 1986. Rapid detection of Agrobacterium tumefaciens in grapevine propagating material and the basis for an efficient indexing system. Plant Dis. 70:566-568.

30. Vancanneyt, G., Schmidt, R., O’Connor-Sanchez, A., Willmitzer, L., and Rocha-Sosa, M. 1990. Construction of an intron-containing marker gene: Splicing of the intron in transgenic plants and its use in monitoring early events in Agrobacterium-mediated plant transformation. Mol. Gen. Genet. 220:245-250

31. Webster, J., and Thomson, J. A. 1986. Agrocin-producing Agrobacterium tumefaciens strain active against grapevine isolates. Appl. Environ. Microbiol. 52:217-219.

32. Winans, S. C., Kerstetter, R. A., and Nester, W. W. 1988. Transcriptional regulation of the virA and virG genes of Agrobacterium tumefaciens. J. Bacteriol. 170:4047-4054.

33. Xiaoying, C., and Wangnian, X. 1986. A strain of Agrobacterium radiobacter inhibits growth and gall formation by biotype III strains of $A$. tumefaciens from grapevine. Acta Microbiol. Sin. 26:193-199. 